\title{
Rural Municipal Development and Reform in Canada: Policy Learning through Local- Provincial Collaboration
}

\section{Commonwealth Journal of Local Governance} Issue 10: December 2011- June 2012 http://epress.lib.uts.edu.au/ojs/index.php/cjlg

\author{
John Martin \\ Director, Centre for Sustainable \\ Regional Communities \\ La Trobe University Bendigo, \\ Victoria, Australia
}

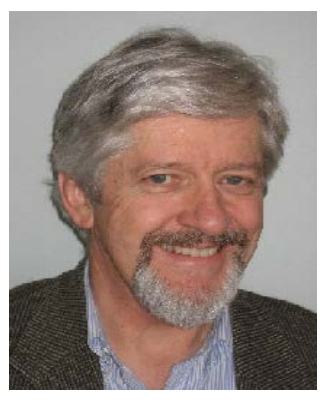

Gary Paget

Senior Policy Advisor, Local

Government Ministry of

Community, Sport \& Cultural

Development

Victoria, British Columbia,

Canada

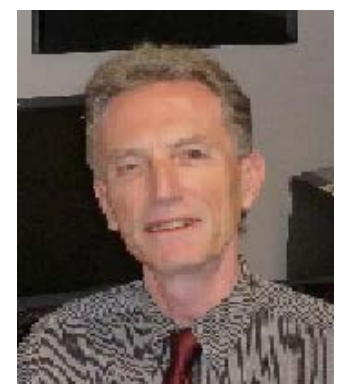

\section{Brian Walisser}

Former Executive Director,

Policy \& Research

Ministry of Community, Sport \&

Cultural Development

Victoria, British Columbia,

Canada

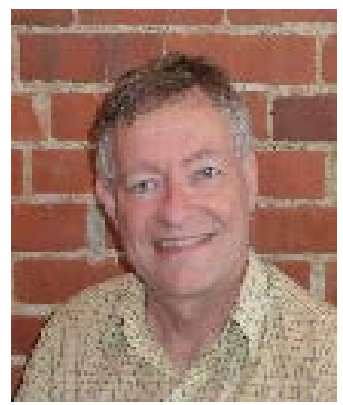

\begin{abstract}
In a federated country like Canada, diversity challenges universal policy prescriptions for local governments. The success of its provincial governments, which have exclusive jurisdiction for systems of local government, depends on balancing the need to act comprehensively and systematically while dealing thoughtfully with the unique situation of individual local governments. Canada's provinces are shifting their approach to strengthening rural governance - shifting away from more directive interventions and now seeking to facilitate capacity-building in a manner that is less state-centred, more bottom-up, and better adapted to variable local circumstances. A dialogue was organised to focus on this shift in provincial practice. It brought together more than 50 savvy and influential policy practitioners representing all provinces and most local government associations at the provincial level. Practice recommendations emerged for provinces, local government
\end{abstract}


associations, and local governments focusing on concrete actions and tools but also on the potential for redefining the roles played by, and relations between, the associations and provincial governments.

\section{Introduction}

The capacity of local governments in western democracies has been of concern to national and state or provincial governments ${ }^{6}$ over the last few decades (Painter, 1991). This applies particularly to thinly populated, low capacity rural municipalities with whom central governments manage a precarious relationship. They are responsible for framing the powers of local governments while also maintaining the capacity of local governments to function as effective local democracies delivering essential services in an efficient and effective manner. Managing this relationship is not easy. While local governments have much in common, it is their diversity that challenges universal prescriptions. Success often depends on how central governments manage to act systematically and comprehensively while still dealing with the unique situation of individual local governments.

Since the federal government is legislatively inactive in the local government sphere, Canada's provinces are responsible for the architecture of local government systems in their territories. As discussed below in section 4, a provincial consensus appears to have developed in the 1960s on pursuing structural reform as a means of strengthening local governance capacity. Although happening in different ways and times, these structural reforms tended to be legislatively imposed and often involved forcible consolidation or regionalization of municipal units: what we will call directive intervention. Most provinces appeared content with this management strategy especially in the 1960s, 70s and 80s.

Since then, contentment has diminished as universal prescriptions for strengthening rural governance continued to face the sector's enormous diversity. Now, Canadian provinces are transitioning toward a strategy of facilitative intervention - which seeks to build capacity in a manner that is less state-centred, more bottom-up, and better adapted to variable local circumstances. Routine networking among the provinces (via communication mechanisms designed to connect deputy ministers and senior policy officials) revealed that, even if they were confident in the need to transition toward facilitative strategies, no province was satisfied that all the management techniques required to make the transition successfully had been acquired or developed.

\footnotetext{
${ }^{6}$ In Canada, the primary parliamentary subdivisions of the federal state are called 'provinces' and 'territories.' In this discussion, references to 'provinces' should be interpreted to include 'territories.'
} 
In 2008, the Symposium on Strengthening the Rural Municipal Sector brought together more than 50 savvy and influential policy practitioners representing all Canadian provinces and most local government associations at the provincial level. The symposium focused on rural governance and cast light on the transition to facilitative intervention - relying on participants to share insights and generate ideas while imparting a sense of opportunity and challenge. Emerging from the symposium was guidance to provinces and local government associations alike. As discussed below in section 5, the guidance focused on concrete actions and tools but was also about changing roles of the provinces, the associations and localities in meeting challenges and the need for new mechanisms to bring these sectors together.

\section{Innovation in Local Government and the Role of Central Government in Local Development}

Innovation in local government is not a topic widely researched in public management. Innovation is often assumed to occur with new and different programs but it is questionable as to whether such initiatives reflect an innovative culture in local government. In 1999, Martin researched a number of award winning local government councils in Australia in an attempt to understand how their innovation process had developed and what the consequences were for councils as a result of having an organisational culture that encouraged innovative thinking and action. Martin's research highlighted "the way in which innovation processes become embedded in the culture of local government organisations” (Martin, 2000, p. 3).

In this paper we are considering innovation within provincial local government systems and between Canadian provinces. It is important to appreciate the context for innovation. Albeit now some time back, Bingham's industry level analysis of innovation in local government identified three key variables that are still relevant today: community environment, organisational environment and organisational characteristics (Bingham, 1976). The issue of innovation in Canadian rural municipal governance has more to do with the first two of Bingham's three variables. The role of the provinces in facilitating innovation and change in rural municipal governance is more about the organisational environment - an environment where each province and the various local government associations work with small rural municipalities to enhance their capacity.

One important change that has occurred in public administration over the last two decades is the focus on NPM or the New Public Management (Barzelay, 2001). Osborne and Gaebler's Reinventing Government (1992) was both a reflection of the vanguard of change sweeping the administration of western governments as well as a call for change in these institutions. 
Hood observed that the NPM was characterised by four underlying themes: an attempt to slow down or reverse government growth; a shift toward privatisation; increased use of information technology in the production and delivery of services; and the development of a more international agenda to public management (Hood, 1991, p. 3). This ideological change has seen a shift away from the traditional top-down approach to administering local government by central government found in traditional public administration. Under NPM, we see a more negotiated environment where local politics plays an important role in the actions of central governments toward strengthening their local governments (Sancton, 2000; Sancton, James, \& Ramsay, 2000).

The normative view of local community development is best represented by Kretzmann and McKnight in their popular book, Building Communities from the Inside Out (1993). They outline an "assets-based approach" to community development where the guiding principle is to identify and engage local assets in the development task. Such publications reflect increasing support for endogenous development in communities, an approach supported by central governments as well as local government. Nevertheless central governments are responsible for their local governments and responding to the diversity of issues across municipalities remains a challenging task.

In developing a theoretical perspective on the role of central government in the governance of rural communities Shucksmith asks "what is the role of the state in promoting sustainable rural communities?” (Shucksmith, 2010, p. 1). He suggests that there has been a shift from a policy focus on integrated rural development focussed on planning, design and infrastructure to one of "place shaping” in which the governance of rural communities, embracing a range of stakeholders and decision-makers, has become the predominant paradigm. HerbertCheshire (2000, p. 203) refers to the discourses of self-help: an ideology "based upon notions of individual and community responsibility, self-help and 'bottom-up' techniques which mobilise the skills and resources of the local community and consequently 'empower' it from the imposing structures of government programmes". The challenge for central governments is to get the right balance of exogenous and endogenous rural municipal development, and universal prescriptions will rarely reflect the great diversity that occurs across systems of local government.

\section{Background on Local Governance in Canada}

Canada is a vast and diverse country with a population of only 34 million. Larger than either Europe or Australia, Canada spans six time zones west to east, stretches from $41^{\circ}$ to $83^{\circ}$ south to north, and covers nearly 10 million $\mathrm{km}^{2}$. 


\section{Governance Context: Federal / Provincial}

Canada is a federal state with 13 provinces (including three province-like territories). Constitutional powers are distributed between the national and provincial governments. Provinces have exclusive jurisdiction for the architecture of the local government systems within their territory, systems that therefore vary in design.

There is no national statute directly influencing the Canadian local government system. However, the national government has used its spending power over the past two decades to address local government infrastructure challenges in fields such as environmental and energy sustainability, water and air quality, and transportation (Berdahl, 2006). At one level, the constitutional division of powers between the national and provincial governments in relation to local government is clear and simple. In practice, however, multi-level government processes in Canada are rather more interdependent and interrelated than it might seem on the surface (Courchene, 1995; Leo, 2006).

\section{Governance Context: Local}

Local governments play an important role in Canada. They generally have similar core responsibilities across the country including transportation and communications, water and waste water, refuse collection/disposal, recreation and culture, land use planning and regulation, and building regulation. Fire and police protection are local responsibilities although, in many provinces, a national police force is available to provide local policing by contract. Local government spending on health, education and social services is minimal as these services have for the most part (with the exception of Ontario) been taken over by provinces (CLGF, 2009; Kitchen \& Slack, 2006; Kitchen, 2002).

Both nationally and provincially, Canadian local governments have combined into local government associations. Associations at the provincial level are particularly influential in policy processes but how this is done varies across the country. Local government associations are unified in most provinces but in others are separated by purpose or language. As a result, there are 19 recognized associations among the 13 provinces.

There is substantial variation among the provincial-level local government associations in terms of capacity and role. A 2007 survey found that about a quarter had only 1 or 2 employees while another quarter were quite large at between 20 and 40+ employees. For each, the key activity is policy advocacy on behalf of local governments. Higher-capacity associations are able to conduct more intensive policy research and analysis while also 
providing a variety of member services (such as fund management and bulk procurement, capacity building and professional development, and/or legal services) ${ }^{7}$.

\section{Profile of the Rural Municipal Sector in Canada}

There is no universal local government system in Canada. Each province differs in its approach to developing a local government system appropriate to its geography, history, economy and social character. However, all provinces face similar rural governance challenges associated with large geographic areas, low population densities, and large numbers of local government units. Today, Canada has in excess of 3600 municipalities (CLGF, 2009), the vast majority of which are small and limited in capacity.

Rural Canada, and especially Canada's northern and Arctic regions, is very sparsely populated. The urban population of Canada surpassed the rural in the 1920's and its growth rates have been higher ever since. Now, according to the latest estimate, 23.2 million or nearly $70 \%$ of Canadians reside in just 33 census metropolitan areas defined by the national statistical agency (Martel \& Caron-Malenfant, 2007; Statistics Canada, 2009).

To comprehend the varying architecture of rural governance systems in Canada, a comparison among selected provinces and territories helps to underline the differing

Table 1: Selected Statistics on Local Government in Selected Provinces, 2006

\begin{tabular}{|c|c|c|c|c|c|c|c|}
\hline & 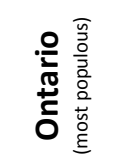 & 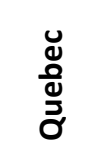 & 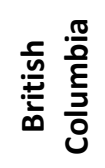 & $\begin{array}{l}\frac{\pi}{4} \\
\frac{\ln }{\alpha}\end{array}$ & 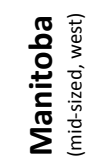 & $\frac{3}{2} \frac{\frac{u}{3}}{\frac{3}{3}}$ & 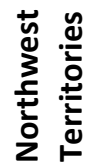 \\
\hline Municipalities (\#): & 415 & 1,117 & 158 & 353 & 201 & 103 & 33 \\
\hline $\begin{array}{l}\text { Municipalities of sub-2000 } \\
\text { population (\#): }\end{array}$ & 116 & 743 & 52 & 213 & 147 & 70 & 29 \\
\hline $\begin{array}{l}\text { Total municipal population } \\
\left({ }^{\prime} 000\right) \text { : }\end{array}$ & $12,075.7$ & $7,498.1$ & $3,600.1$ & $3,243.7$ & $1,148.4$ & 457.0 & 40.8 \\
\hline $\begin{array}{l}\text { Total non-municipal } \\
\text { population ('000): }\end{array}$ & 84.5 & 48.0 & 513.4 & 46.6 & 0 & 273.0 & 0.1 \\
\hline $\begin{array}{l}\text { Total population of largest } \\
\text { five municipalities ('000): }\end{array}$ & $4,922.3$ & $2,952.0$ & $1,474.1$ & $1,958.5$ & 714.1 & 219.4 & 30.1 \\
\hline $\begin{array}{l}\text { Total population of sub-2000 } \\
\text { cohort ('000): }\end{array}$ & 95.3 & 641.0 & 48.7 & 114.7 & 127.6 & 65.8 & 12.6 \\
\hline $\begin{array}{l}\text { Number of municipalities in } \\
\text { decline (2001-2006): }\end{array}$ & 137 & 510 & 74 & 117 & 118 & 73 & 5 \\
\hline $\begin{array}{l}\text { Average municipal } \\
\text { population: }\end{array}$ & 29,098 & 6,713 & 22,785 & 9,189 & 5,381 & 4,437 & 1,237 \\
\hline $\begin{array}{l}\text { Median municipal } \\
\text { population: }\end{array}$ & 5,818 & 1,207 & 4,306 & 1,010 & 1,003 & 1,291 & 460 \\
\hline
\end{tabular}

\footnotetext{
${ }^{7}$ From information compiled by the provincial-level local government associations in 2007; shared with one of the authors as part of routine local/provincial information exchange.
} 
circumstances faced (see Table 1). Selected information is provided on the four most populous provinces, two mid-sized provinces from the west and east respectively, and one northern territory. Together, this sample represents over $90 \%$ of the Canadian population.

It is clear from the data that, despite a high level of urbanization in most Canadian provinces, municipalities are typically many in number and small in size. With the exceptions only of Ontario and British Columbia, one can expect provinces to have more than one municipality per 10,000 of population. The median population for municipalities is usually in the range of only 1000 persons - very small indeed. This is a reflection of Canada's immense spaces and relatively small population.

\section{Evolution of Provincial Policy toward Governance Structures}

Coupled with the fact that provinces are constitutionally responsible for local government, the twin challenges of vastness and diversity are a recipe for considerable variation in both the architecture of systems for local governance and in the approaches taken by provinces toward strengthening local governance in their jurisdictions.

\section{Strengthening Local Governance - Era of Directive Intervention}

Beginning about 1960, the provinces started to rely on structural reform for strengthening local governance. According to observers (O'Brien, 1993; Sancton, 1993), and consistent with the authors' experience as provincial officials, structural reform has often involved consolidating municipal units or introducing regional or two-tier local government formations. Furthermore, such reforms have tended to be imposed rather than negotiated.

The period of intense provincial interventions to reform local government structures dates back at least as far as 1953 and the introduction of two-tier local government in Toronto. Sancton (1993) describes several major interventions that followed across the country:

Manitoba - reforms to Winnipeg's governance structure in 1960 (two-tier) and 1972 (singletier consolidation)

Québec - formation (in 1970) of two-tier “urban communities” in Montréal and Québec; later, provincially-imposed mergers to form today’s Laval and Longueuil

Ontario - in the 1970s, the creation of two-tier regional formations in most major centres outside Toronto

New Brunswick - a "drastic" provincial reform initiative (1967) to create a new and "scarcely recognizable" local government system

Alberta - a continuing tradition of annexing territory to its two major cities, Calgary and Edmonton; a consolidation initiative to create the municipality of Crowsnest Pass 
Provincial activism, or what one might label directive intervention, is one common denominator in all these structural initiatives. Indeed, hindsight makes clear that structural reform was a major preoccupation in many (certainly the most populous) provinces over the three decades from 1950 to 1979. In only isolated instances have observers of this period identified a different approach to strengthening local and rural governance.

\section{Strengthening Local Governance - Transition to Facilitative Intervention}

This alternative approach, less state-centred and more bottom-up, is what one might label facilitative intervention. British Columbia was one early adopter, employing a "strategy of gentle imposition” (Tennant \& Zirnhelt, 1973) when introducing a system for federated regional governance beginning in 1965 . The system introduced relied on local choice both for establishing individual regional districts and for assigning their functions thereafter in a process of continuous evolution (BC-MCSCD, 2010). A strategy of gentle imposition also underpinned the roll-out of Québec's system of RCM's or regional county municipalities. In 1979, traditional counties were converted to RCM's but without specifying either boundaries or the exact composition of their governing councils, which were to be negotiated, in the authorizing legislation (Sancton, 1993, pp. 15-18).

In 1993, Sancton wrote that the "days of large-scale centrally imposed municipal reorganisation are clearly over” (1993, p. 40). He was premature. Since 1995, significant directive interventions to reform local government structures took place in Nova Scotia (Halifax, Cape Breton), New Brunswick (Miramichi), as well as among metropolitan and non-metropolitan local governments in both Québec and Ontario (Sancton, 2003).

However, more recent evidence suggests Sancton's assessment was early but essentially correct. Almost all provinces are moving away from directive amalgamation and regionalisation and appear to be developing robust, multifaceted facilitative intervention techniques. Evidence includes:

- Cessation of recent, provincially-led amalgamation initiatives by Ontario and Québec (Sancton, 2006)

- The new focus on capacity-building and facilitated change management in Alberta, Saskatchewan and Manitoba (C-SPO, 2008)

- The establishment or continuation, in Newfoundland and British Columbia respectively, of "gentle” programs for strengthening rural governance (C-SPO, 2008)

Grounded in a different conception of how provinces relate to their local government sector, emerging practices among the provinces indicate an important shift toward collaborative 
engagement. Further evidence may be advanced. First, there is growing reliance among the provinces on a new model of intensive collaboration with local government associations in developing new and more broadly empowering local government legislation. ${ }^{8}$ Second, under Québec's sophisticated rural policy, the focus is on rural regional vitality through integrated or "joined-up” multi-level governance. The policy is a deliberate attempt to harness energies across a broad spectrum of parties interested in rural development. Under the second consecutive "rural pact", extending through 2014, the province has committed to solidifying the gains made in the 2002 pact and to working through committees of partners (Comité des partenaires de la ruralité) and elected officials (Conférences régionales des élus) to improve horizontal and vertical coordination of initiatives (C-SPO, 2008; Province of Québec, 2011). Third, and in relation to rural governance nation-wide, engagement can be illustrated with

Table 2: mechanisms employed by provinces to strengthen rural governance

\begin{tabular}{|l|l|}
\hline \multirow{4}{*}{ Structural Measures } & Amalgamation processes \\
\cline { 2 - 2 } & Regionalism processes \& institutions \\
\hline \multirow{4}{*}{$\begin{array}{c}\text { Measures Relating to } \\
\text { Building Capacity }\end{array}$} & Technical guideline issuance \\
\cline { 2 - 2 } & Human resource initiatives \\
\cline { 2 - 2 } & Advisory services \\
\cline { 2 - 2 } & Communications support \\
\cline { 2 - 2 } & Training initiatives and programs \\
\cline { 2 - 2 } $\begin{array}{c}\text { Measures Relating to } \\
\text { Improving Coordination }\end{array}$ & Policy implementation support \\
\cline { 2 - 2 } & Innovation \& best practice initiatives \\
\hline \multirow{3}{*}{$\begin{array}{l}\text { Financial and Resource } \\
\text { Measures }\end{array}$} & Vertical coordination facilitation \\
\cline { 2 - 2 } & Horizontal coordination facilitation \\
\cline { 2 - 2 } & Legislative powers \\
\cline { 2 - 2 } & Transfers (tied / untied) \\
\cline { 2 - 2 } & Borrowing processes \& institutions \\
\hline
\end{tabular}

Source: from 2008 survey returns from provincial ministries responsible for local government; compiled by one of the authors as part of routine interprovincial information exchange

reference to a growing range of collaborative mechanisms employed by the provinces, as shown in Table 2. Facilitative intervention is emerging as the norm.

\section{Symposium on Strengthening the Rural Municipal Sector: Deepening Understanding of Facilitative Intervention}

Late in 2008, there was a unique opportunity to explore the practice of rural municipal governance in Canada. A very experienced group of governance practitioners assembled for the Symposium on Strengthening the Rural Municipal Sector. Reflecting the highly disaggregated municipal sector in Canada, never before had such a high-ranking group of

\footnotetext{
${ }^{8}$ The development of Ontario Bill 130 or the Municipal Act, 2006, is one example among many (see www.mah.gov.on.ca/Page184.aspx, retrieved July 2011).
} 
government professionals been convened for intensive, interactive dialogue around an issue like rural municipal governance.

The event was framed in the context of the changing concept of local-provincial relations outlined in the preceding section. In particular, a key objective was to create a platform for policy learning. Spicer (2010), cites one broad definition of policy learning as a "process of evaluating new policy ideas, past practices and foreign precedents” in order to identify pathways to improved performance.

\section{The Symposium's Design}

The design of the symposium was informed by two skilled scholar-practitioners, one Canadian, one Australian. ${ }^{9}$ In a nutshell, the methodology selected involved:

- Choosing participants from among the most experienced rural governance practitioners in all parts of Canada

- Supplying common information on the range of practices across the country ${ }^{10}$

- Creating opportunities for direct, face-to-face intergovernmental dialogue around successes, failures, and future opportunities in relation to rural governance (C-SPO, 2009, pp. 17-20)

- Challenging individual participants at the conclusion of the symposium to contribute specific ideas and reflections on rural governance reform (C-SPO, 2009, pp. 22-23)

An elite corps of more than 50 governance practitioners gathered in Québec City for the symposium. Every province and most of the 19 local government associations were represented by senior officials. Typically, those attending included heads or deputy heads of agency or senior policy professionals. Each of the co-authors of this paper attended the symposium, one as chief organiser, another as discussion facilitator, and the third as a participant / presenter.

\section{Symposium Outcomes: Policy Learning}

The following discussion focuses on synthesizing symposium outcomes produced from small group discussion (designed to encourage a frank exchange of views among participants) and from written post-symposium reflections provided by participants (intended

\footnotetext{
${ }^{9}$ The Canadian then headed the Rural \& Small Town Programme (Mount Allison University, Sackville NB). The Australian heads the Centre for Sustainable Regional Communities (La Trobe University, Bendigo VIC).

${ }^{10}$ See the symposium document server at www.muniscope.ca/home/Symposium/index.php (retrieved July 2011) for all materials provided to participants prior to or at the symposium.
} 
to elicit their recommendations for reform after benefitting from the symposium's facilitated dialogue ${ }^{11}$ ). In short, the focus is on the products most likely to embed policy learning.

\section{New views about structure and system architecture}

Symposium participants were concerned about the overall architecture (powers, decisionmaking processes, structures) of the rural governance systems in the provinces. Participant recommendations for strengthening the rural governance architecture far outnumbered any other recommendation among post-symposium reflections submitted.

However, only a very small proportion of symposium participants recommended the classic approach of imposed structural reform to create large municipal units by amalgamation. A slightly larger proportion of participants shared the view that less fragmentation among local governments would increase effectiveness but rejected directive intervention as a technique. From the latter group, recommendations were framed around soft-power strategies (such as incentives or practice guidance) for stimulating regionalization, interlocal collaboration and shared services.

Interestingly, among participants who favoured structural reforms, the largest proportion of respondents favoured an approach that attaches more significance to the process of structural reform than to the outcome of reform initiatives. These respondents appear to have concluded that regional cooperation is best built on a voluntary platform, driven by mutual benefits, flexibility, and incentives. Opinions differed about where - if not on provinciallyinspired directive intervention - to place the onus: a) some espoused voluntary action emerging from needy local governments themselves; b) others promoted a new role for local government associations in managing structure change; c) still others viewed the issue more in terms of managing the politics of obtaining formal or, more commonly, informal voter consent for structural reform measures.

Downsides and barriers to strengthening the architecture of rural governance systems were also touched upon by participants. Some pointed toward the inadequacy of provincial legislative frameworks either because in their view: a) existing legislation creates unintended barriers for interlocal cooperation, or b) existing legislation fails to lever sound performance out of the rural municipal sector. Thus, some participants called for provincial legislative adjustments where required. Examples cited included introducing comprehensive

\footnotetext{
${ }^{11}$ Participants were asked to reflect on the symposium and to submit three recommendations for strategic change to improve governance in the rural municipal sector - change that could be accomplished: a) by the local government sector working in its own sphere of self-determination: b) by provincial governments working to modify the "architecture" of the system for rural governance; and c) by the municipal and provincial spheres together, working in tandem to improve governance outcomes. Full results are documented (C-SPO, 2009).
} 
frameworks for inter-municipal collaboration under provincial legislation and legislation making comprehensive five-year service and financial plans mandatory. And while encouraging provinces to reinforce the transition toward facilitative modes of intervention, the sometimes achingly slow progress of voluntarism was occasionally cited as a concern.

Possibly as a result of concern over the prospect of glacial progress under purely voluntary reform strategies, some symposium participants appeared to be impressed by Québec's comprehensive rural strategy (QC-MAMROT, 2006), and called for similar action in other provinces. What is attractive about the strategy is its assumption that rural communities have the capacity to take their development into their own hands. According to the Québec ministry, the strategy enables rural communities to put forward initiatives based on their own priorities, is focused on mobilization and partnership, is designed to be flexible, and fosters innovation and support (C-SPO, 2008). Symposium participants saw this strategy as a model for establishing facilitative provincial policy frameworks to guide progress on rural governance reforms while still maintaining the voluntary, facilitative approach that is becoming so valued. As framed by one of the small group panels, propelling reform through strategic frameworks must be "flexible, non-intrusive, and adaptable” (C-SPO, 2009, p. 19).

\section{Interest in improving coordination practices}

Symposium participants strongly supported horizontal and vertical coordination or "joinedup governance" but appeared to find tangible evidence of effective coordination practices to be lacking. Joined-up governance has a number of dimensions:

- Horizontal coordination within the local government sector (interlocal)

- Vertical coordination between provincial and local governments (intergovernmental)

- Horizontal coordination between provincial ministries or departments (interministry)

The symposium revealed that local government associations and provinces share a common interest in developing the tools to support interlocal coordination through regionalism, interlocal collaboration and shared service arrangements. This was somewhat surprising in that it points to a role for associations that is beyond their traditional role as advocates for, but not participants in, reform initiatives. At least some local government associations view change management as not purely a provincial role; they saw themselves becoming active in promoting dialogue on improving governance mechanisms. It was seen as a "two-way street" with both provinces and associations benefitting. Participants felt that sharing best practices both within and between provinces would help. 
There was agreement that vertical coordination between the provincial governments and local governments is essential. Participants concluded that more effort by the provinces to achieve this is necessary. Symposium participants showed concern that unstable or unpredictable arrangements interfered with achieving common objectives in rural areas, and some believed long-term intergovernmental financial agreements could lessen instability. One example cited was Québec's fiscal and financial partnership (Partenariat fiscal et financier). Under this agreement, the province agrees to supplement Québec local government revenues in exchange for intergovernmental agreement on goals.

Symposium participants also agreed that properly designed infrastructure programs can be vital for levering regional or interlocal action. Some participants believed that provincial and federal infrastructure funds could be used to promote collaborative action but were not being used effectively. The concern was that traditional programs reinforce atomization and result in locally-oriented or parochial solutions rather than regional or interlocal cooperation. Some participants were attracted to British Columbia's experience in using "smart" grant programs, an example being the implementation of the federal gas tax transfer agreement (where a portion of available funds is dedicated to a "regionally-significant project fund", encouraging infrastructure projects that produce regional as opposed to purely local benefits).

At the same time there was recognition that neither structural reform nor incentives are by themselves sufficient - effective implementation processes are required. Québec's unique approach of bringing provincial, regional and local elected officials together through regional conferences of elected officers (Conférences régionales des élus) appeared to be influential among participants. These intergovernmental bodies have the mandate to consult horizontally and vertically to address implementation of agreed objectives (QC-MAMROT, 2011). Generally, participants seemed to form a strong view that provinces needed to focus on improving both intergovernmental and interministry coordination practices and make “joined-up governance” a reality.

\section{In search of effective capacity-building}

Symposium participants agreed that rural or rural regional governments are apt to need considerable support to build their capacity to manage change. Capacity building includes providing support through advice, providing data and technical guidelines, information on leading practices, and the training of elected and non-elected officials. 
Traditionally, capacity building has been seen as an exclusive responsibility of the provinces. Some symposium participants, however, showed that their thinking is migrating toward the view that local government associations and provinces together must take responsibility for capacity building. In addition, the view was expressed that localities must take more responsibility for managing their own internal affairs. This requires local governments to move beyond mere compliance with provincial legislative requirements or policy prescriptions. Symposium participants pointed toward a need for communities themselves to take responsibility for monitoring their health and choosing their responses. Participants viewed Manitoba's self-assessment tool (AMM, 2011), developed as a local / provincial partnership, as a model approach. The online self-assessment tool (search on "tools change municipal health checklist Manitoba") helps Manitoba communities measure five key indicators of local strength or well-being - including indicators such as tax base growth and diversity and community engagement and support. ${ }^{12}$

The symposium discussed a number of actions provinces and local government associations could take to strengthen capacity. For example, participants recommended:

- Leading practice guidance and policy guidelines regarding governance and financial management, especially to assist the most vulnerable centres (one specific need relates to leading practices in the interlocal and intergovernmental domains)

- Easier access to appropriate statistical data (such as data relevant to self-assessment) that is synthesized at an appropriate scale (noting that Canadian data tends not to be aggregated by statistical bodies at a supra-municipal scale)

- Additional stress on supporting rural and rural-regional governments to convert policy into action (recognizing the need for sensitive, place-based adaptations for generic policies)

In all such action spheres, the evidence is that some of the local government associations viewed themselves advancing toward sharing responsibilities (and risks) with the provinces. In Canada, sharing responsibilities in this manner is not an established practice among either the provinces or the associations. That some local government associations are migrating in their thinking is another indicator of the on-going attitudinal shift in provincial-local relations discussed in section 4 .

A key component of capacity is leadership, from both elected and non-elected officials. Participants agreed that there is a role both for provinces and local government associations

\footnotetext{
${ }^{12}$ A good summary of cross-Canada interest in self-assessment is presented on the website of Saskatchewan's local government ministry: www.municipal.gov.sk.ca/MID/Sustainability (retrieved July 2011).
} 
in leadership training. The principal challenge is "leading outward", building relationships and partnerships with other local governments, provincial and federal governments, and various stakeholders. Participants took notice of British Columbia's Local Government Leadership Academy (lgla.ca), a partnership of the province, the local government association, and other local government stakeholders.

\section{Conclusion}

The diversity of a federated country like Canada challenges universal provincial policy prescriptions for local governments. The success of its provincial governments depends on how well they balance the need to act comprehensively and systematically while dealing thoughtfully with the unique situation of individual local governments. Acting flexibly yet comprehensively will be easier for provinces in Canada that embrace the shift reflected in the New Public Management, the shift away from a traditional top-down approach to administering local government toward a more collaborative, negotiated stewardship of their local government systems. The 2008 symposium on rural local governance reported in this paper yielded valuable insights on practical ways to manage the shift toward collaborative system management.

While the New Public Management remains topical, the fact is that it has been topical for at least two decades - and is no longer especially "new". In the abstract, it is easy to comprehend the virtue in shifting toward collaborative stewardship. That Canadian practitioners are still struggling, two decades on, to achieve genuinely meaningful forms of collaboration in practice is a measure of how difficult it is to change a long-established management culture of unilateralism and replace it with a new philosophy of collaborative system management. It is difficult on many levels: defining the proper set of collaborative mechanisms, reorienting the behaviours of decision-makers and other officials, and sustaining a new culture of collaboration given the volatile and recurrent political and economic pressures that governments routinely face.

Some of the recommendations ventured by symposium participants called for, in a Canadian context, collaboration to an unprecedented degree and depth, going well beyond the mere notion of intergovernmental consultation prior to decision-making. For instance, there were advocates for defining new roles for local government associations, achieved either by intervening in and helping resolve contentious structural problems or by teaming with provinces to set strategic directions for system reforms. Implementing what amounts to a system co-management arrangement would be very difficult in most countries. When faced with an established culture of unilateralism, one is bound to ask whether achieving such a dramatic shift in management philosophy is an attainable goal. There are several reasons to 
be wary. For one, a central government might not accept having its freedom of action curtailed under a joint system management scheme. Second, a local government association might actually be reluctant to accept the responsibilities and risks inherent in genuine comanagement. Finally, the capacity of local government associations and even some central governments might not be adequate to execute a successful transition.

While the 2008 Canadian symposium sought to identify recommendations for reforming rural governance systems, it did not focus on implementation requirements. Any central government contemplating reforms of the type identified in this analysis will need to develop a resilient change management plan. First, that government will need to launch the transition with clear communication around the vision for and direction of change. Second, the central government will need to carefully shape the institutional environment - engaging with local governments in determining objectives, providing the right legislative framework, using "smart" incentives, furnishing support for capacity building at the central and local government levels, and encouraging tolerance for implementation setbacks. Third, noting that situational readiness will vary from country to country, wise counsel would be to approach implementation in a selective, phased or experimental manner, aiming to build toward a solution in an evolutionary manner. Fourth, any local government association intent on meaningful collaboration will need to consider overhauling its own mandate - given that shared system management implies going beyond the traditional role of advocacy and accepting both the responsibilities and risks inherent in playing an expanded role as a partner in reform. Finally, all participants will face the challenge of developing the requisite skills in leadership and diplomacy.

\section{Disclaimer}

* The views expressed are those of the authors and do not reflect the views of the Government of British Columbia, the British Columbia Ministry of Community, Sport \& Cultural Development, or any other Canadian official. 


\section{References}

AMM. (2011). Tools for Change. Retrieved January 2011, from Association of Manitoba Municipalities (AMM): www.amm.mb.ca/res_tools.html

Barzelay, M. (2001). The New Public Management: Improving Research and Policy Dialogue. University of California Press.

BC-MCSCD. (2010). Regional Districts, Parts 1 to 3. (S. Russo, \& B. Walisser, Eds.) Retrieved January 2011, from Ministry of Community, Sport \& Cultural Development, Government of British Columbia: www.cd.gov.bc.ca/lgd/history/mini_histories

Berdahl, L. (2006). The Federal Urban Role and Federal-Municipal Relations. (R. Young, \& C. Leuprecht, Eds.) Retrieved June 2011, from Canada: The State of the Federation 2004: Municipal-Federal-Provincial Relations in Canada: www.ppm-ppm.ca/publicationssotf04.asp

Bingham, R. (1976). The Adoption of Innovation by Local Government. Toronto: Lexington Books.

Bollman, R., \& Clemenson, H. (2008). Structure and Change in Canada's Rural Demography: An Update to 2006 with Provincial Detail. Retrieved June 2011, from Statistics Canada, Agriculture and Rural Working Paper Series: www.statcan.gc.ca/pub/21-601-m/21-601m2008090-eng.pdf

CLGF. (2009). Local Government System in Canada. Retrieved January 2011, from Commonwealth Local Government Forum (Country Profiles): www.clgf.org.uk/index.cfm/PageID/13/ViewPage/Country-profiles

Courchene, T. J. (1995). Celebrating Flexibility: An Interpretive Essay on the Evolution of Canadian Federalism. Montréal: C.D. Howe Institute.

C-SPO. (2009). Final Report. Retrieved April 2011, from Symposium on Strengthening the Rural Municipal Sector [Caucus of Senior Policy Officials]:

www.muniscope.ca/_files/file.php?fileid=fileysYCGUoseM\&filename=file_Symposium_2008 _FINAL.pdf

C-SPO. (2008). Provincial Feature Presentations. Retrieved June 2011, from Symposium on Strengthening the Rural Municipal Sector [Caucus of Senior Policy Officials]: www.muniscope.ca/home/Symposium/index.php

Herbert-Cheshire, L. (2000). Contemporary Strategies for Rural Community Development in Australia: a Governmentality Perspective. Journal of Rural Studies , 16 (2), 203-15.

Hood, C. (1991). A Public Management for All Seasons? Public Administration , 69 (1), 3-19.

Kitchen, H. (2002). Canadian Municipalities: Fiscal Trends and Sustainability. Retrieved June 2011, from Canadian Tax Journal: www.ctf.ca/ctfweb/Documents/PDF/2002ctj/2002ctj1_kitchen.pdf

Kitchen, H., \& Slack, E. (2006). Trends in Public Finance in Canada. Retrieved June 2011, from The Institute on Municipal Finance and Governance:

www.utoronto.ca/mcis/imfg/pdf/trends\%20in\%20public\%20finance\%20in\%20Canada\%20\%20June\%201.pdf

Kretzmann, J. P., \& McKnight, J. L. (1993). Building Communities from the Inside Out: A Path Toward Finding and Mobilizing a Community's Assets. Evanston, IL: Institute for Policy Research.

Leo, C. (2006). Deep Federalism: Respecting Community Difference in National Policy. Canadian Journal of Political Science , 39 (3), 481-506. 
Martel, L., \& Caron-Malenfant, É. (2007). Portrait of the Canadian Population in 2006: Population and Dwelling Counts, 2006 Census. Retrieved January 2011, from Statistics Canada: www12.statcan.ca/census-recensement/2006/as-sa/97-550/index-eng.cfm

Martin, J. (2000). Innovation Strategies in Australian Local Government (Occasional Paper 4). Retrieved May 2011, from Australian Housing \& Urban Research Institute: www.ahuri.edu.au/downloads/publications/Occasional_Paper_4.pdf

O'Brien, A. (1993). Municipal Consolidation in Canada and its Alternatives. Retrieved January 2011, from Muniscope (ICURR Press Publications Archive): www.muniscope.ca/library/publications/index.php\#Municipal

Osborne, D., \& Gaebler, T. (1992). Reinventing Government: How the Entrepreneurial Spirit is Transforming the Public Sector. Reading, MA: Addison-Wesley.

Painter, M. (1991). Intergovernmental Relations in Canada: An Institutional Analysis. Canadian Journal of Political Science , 24 (2), 269-88.

Province of Québec. (2011). Mandat : Conférences régionales des élus (CRÉ). Retrieved January 2011, from Portail Québec:

www.formulaire.gouv.qc.ca/cgi/affiche_doc.cgi?dossier=8996\&table=0

QC-MAMROT. (2011). Conférences régionales des élus. Retrieved April 2011, from Québec Ministère des Affaires municipales, Régions et Occupation du territoire: www.mamrot.gouv.qc.ca/developpement-regional-et-rural/conferences-regionales-des-elus

QC-MAMROT. (2006). National Policy on Rurality, A Source of Strength for Québec, 2007-2014. Retrieved April 2011, from Québec Ministère des Affaires municipales, Régions et Occupation du territoire: www.mamrot.gouv.qc.ca/pub/developpement_regional/ruralite/politique_nationale_ruralite/rur alite_politique_angl.pdf

Sancton, A. (1993). Local Government Reorganization in Canada since 1975. Retrieved January 2011, from Muniscope (ICURR Press Publications Archive): www.muniscope.ca/library/publications/index.php\#Municipal

Sancton, A. (2000). Merger Mania: The Assault on Local Government. McGill-Queen’s University Press.

Sancton, A. (2006). Municipal Mergers and Demergers in Quebec and Ontario. Retrieved January 2011, from Annual Meeting of the Canadian Political Science Association, 2006: www.cpsaacsp.ca/papers-2006/Sancton.pdf

Sancton, A. (2003). Why Municipal Amalgamations? Halifax, Toronto, Montréal. Retrieved January 2011, from Institute of Intergovernmental Relation (Queen's University, Kingston ON): www.queensu.ca/iigr/conf/Arch/03/03-2/Sancton.pdf

Sancton, A., James, R., \& Ramsay, R. (2000). Amalgamation vs. Inter-Municipal Cooperation: Financing Local and Infrastructure Services. Retrieved May 2011, from Muniscope (ICURR Press Publications Archive): www.muniscope.ca/_files/file.php?fileid=fileNipcFCJvOK\&filename=file_amalgamation_vs.p $\mathrm{df}$

Shucksmith, M. (2010). Disintegrated Rural Development? Neo-endogenous Rural Development, Planning and Place-Shaping in Diffused Power Contexts. Sociologia Ruralis , 50 (1), 1-14. 
Spicer, Z. (2010, November). Institutional Policy Learning and Formal Federal-urban Engagement in Canada. (G. Sansom, Ed.) Retrieved January 2011, from Commonwealth Journal of Local Governance (Issue 7): epress.lib.uts.edu.au/ojs/index.php/cjlg/article/view/1892/2035

Statistics Canada. (2006a). Census subdivision types by province and territory. Retrieved June 2011, from Census 2006: www12.statcan.ca/census-recensement/2006/ref/dict/tables/table-tableau-7eng.cfm

Statistics Canada. (2006b). Population and dwelling counts. Retrieved June 2011, from Census 2006 : www12.statcan.ca/census-recensement/2006/dp-pd/hlt/97550/Index.cfm?TPL=P2C\&Page=FLTR\&LANG=Eng\&T=302\&S=1\&O=A

Statistics Canada. (2009). Population of census metropolitan areas (2006 Census boundaries). Retrieved January 2011, from Statistics Canada: www40.statcan.ca/101/cst01/demo05aeng.htm

Tennant, P., \& Zirnhelt, D. (1973). Metropolitan Government in Vancouver: the Strategy of Gentle Imposition. Canadian Public Administration , 16 (1), 124-138. 